\title{
The Application of Numbered Heads Together (NHT) in Online Learning
}

\author{
Febrian Solikhin $^{\mathrm{a}, \star}$, Weni Inda Sarib ${ }^{\mathrm{b}}$ Krisna Dewic \\ ${ }^{a}$ Chemistry Education Study Program, University of Bengkulu \\ ${ }^{b}$ Student of Chemistry Education Study Program, University of Bengkulu \\ ${ }^{c}$ Public Senior High School of 3 Bengkulu City \\ *Corresponding author: febrian.solikhin@unib.ac.id
}

Received: May 20, 2021; Accepted: July 21, 2021; Published: October 15, 2021

\begin{abstract}
This research is a Classroom Action Research conducted at Public Senior High School 3 Bengkulu City, especially class XI MIPA 4. Online learning in this class reduces student learning activities. Many students are passive in learning. This affects decreasing their learning outcomes. For that, it is necessary to provide the appropriate treatment for solving the problem. This treatment is to apply a learning model that requires students to be more active in learning. One of them is the Numbered Head Together $(\mathrm{NHT})$ learning model. This study aims to increase student activeness in the online learning process and improve student learning outcomes using the NHT model, especially chemical equilibrium material. The subjects of this study were 34 students of class XI MIPA 4. The instruments used were the student activeness observation sheet and the learning outcome test instrument. This research runs in 2 cycles, with each cycle consisting of planning, implementing, observing, and reflecting. The results obtained, overall, there was an increase in student activity in the online learning process and student learning outcomes. The percentage of student activeness in online learning increased from $40.19 \%$ in cycle I to $85.29 \%$ in cycle II. Meanwhile, the percentage of student learning outcomes completeness risen from $55.88 \%$ in the first cycle to $82.35 \%$. Both have achieved the target set, which is $75 \%$.
\end{abstract}

Keywords: Activeness, Classroom Action Research, Learning Outcomes, Numbered Head Together

\section{INTRODUCTION}

Education is one of the foundations in the nation's life and state, both formal and non-formal education. Both of them complement each other in the educational process. Schools, as one of the legal educational institutions, are required to carry out education well. This is an effort to get a generation that is ready to compete in society. The learning process at school helps students to develop their abilities so that they can achieve learning goals. When goals have been set, students will direct their attitudes in achieving these goals [1]. The goal is one of the learning components. Learning will not work well if the learning components do not interact simultaneously [2]. For that, teachers, students, and learning objectives must interact well so that learning can be optimal.

The 2013 curriculum is the first curriculum that emphasizes student-centered learning. This kind of learning is preferred by students [3]. This curriculum requires students to be more active in their learning. Students are not only objects but become subjects in learning. This makes teachers constantly innovate in every lesson they take. Teachers must be creative in stimulating students to think to find problems. In the 2013 curriculum, the roles of teachers and students should equal in the learning process to create an energetic, and conducive atmosphere. For this reason, there is a curriculum update aimed at introducing innovative methods and making the history of education better [4].

On the other hand, the COVID-19 pandemic has reduced classroom learning or even eliminated it. Currently, learning is carried out in a hybrid between face-to-face and online. This is so that the chain of 
the spread of the coronavirus can be broken. Consequently, the learning change from offline to online learning or learning from home. This online learning can be done using synchronous or asynchronous methods. Both have their own advantages and disadvantages. There are also various platforms that teachers can use, such as zoom meetings, google meet, WhatsApp, and others. However, in practice, students prefer learning using zoom meetings [5].

So far, online learning has mostly been done by simply sending material through the WhatsApp group, then discussions are held there. When using zoom meetings or google meet, the teacher only conducts learning with the lecture method. This is not effective for application the 2013 curriculum to make students more active in learning. Students become passive and do not have a good learning experience. The passivity of students will result in a decrease in their learning outcomes. In increasing student activity and student learning outcomes, teachers must be innovative in choosing the right learning model. In implementing the 2013 curriculum, this learning model is still not optimal $[6,7]$. The learning model used is a learning model that is in accordance with the demands of the curriculum and can make students active when learning in online classes. One of the learning models that can be used is the Numbered Head Together (NHT) learning model.

The NHT model is one type of cooperative learning model that promotes students learning in small group discussions in the classroom [8]. In the learning process, students will be divided into groups and given different numbers. The number that will be called by the teacher will convey the results of the discussion or answer questions from the teacher. This learning model makes students more active in group discussions and communicates the results to other students. Therefore, this model is suitable for increasing student activeness in the classroom [9]. This increase in student activity will have an effect on their learning outcomes. The NHT model has four main steps, namely numbering, questioning, thinking together (heads together), and answering [10].

Chemistry is a science subject at the secondary school level. This chemistry deals with chemical reactions and changes in everyday life. One of the materials in this chemistry subject is chemical equilibrium. This material is one of the most challenging materials, according to students [11]. Teachers must be innovative in choosing the suitable model in teaching this material. Based on the results of an interview with a chemistry teacher for Class XI MIPA 4 SMA Negeri 3 Bengkulu City, the learning process was carried out using google classroom only, once or twice using a zoom meeting. This was because some students argued that their home network was not good. This lack of networking makes students often miss classes. Even when attending class, many of them are only listeners. This makes online learning that is carried out not optimal in meeting the demands of the 2013 curriculum. For this reason, it is necessary to use an appropriate learning model in the learning process of chemistry materials in this class, especially the use of the NHT learning model, which is able to increase student activity in the classroom [12]. This study aims to increase student activeness in the online learning process and improve student learning outcomes using the Numbered Head Together (NHT) learning model. This learning model is one of the recommended learning models for the 2013 curriculum that can make students more active in their learning.

\section{METHOD}

This research is classroom action research (CAR). This research was conducted in natural science class XI MIPA 4, Public Senior High School (SMA Negeri) 3 Bengkulu City. CAR begins with class problems that must be resolved. The problem of this class is the passive students in the learning process. This makes their learning outcomes lower for the previous material, namely the reaction rate. The material for the rate of reaction is the basis of knowledge to enter into the material of chemical equilibrium. It is well known that chemical equilibrium is a reversible reaction in which the rate of reaction for the formation of products is equal to the rate of reaction of the reactants. Both take place at the same speed and time. For this reason, the purpose of this study is to increase student activeness in learning and student learning outcomes for equilibrium material. The research subjects in this class were 34 students consisting of 27 female students, and the rest were boys.

The instrument used in this study was the class activeness observation sheet that used a checklist and a test instrument that was used as a means of measuring student learning outcomes at the end of each learning cycle. The class activeness observation sheet consists of 3 aspects, namely issuing opinions during group discussions, providing appropriate arguments, and providing relevant questions. Each student 
who expresses an opinion in every aspect is given 1 point on the checklist. The number of issues can then be classified into active, active, moderately active, less active, and inactive criteria.

This CAR is carried out in several cycles, with each cycle consisting of planning, implementing, observing, and reflecting. This step is in accordance with the CAR Model according to Kemmis and Tagart [13]. The planning stage is used to plan and organize the learning process carried out in the classroom. This planning includes making lesson plans and making test instruments. The lesson plans used are online learning lesson plans with the NHT learning model. The developed test instrument contains ten questions in each cycle. This question consists of 6 Multiple choice and 4 Descriptions. The implementation stage includes the treatment of the NHT learning model in its learning. This learning is carried out using the Zoom meeting and WhatsApp group. The observation stage was carried out by observers and researchers when learning in class, including in small group discussions. This stage uses an observation sheet that has been prepared previously. In group discussions, each group was accompanied by one observer. The reflection stage is the stage to see the results of observations and tests. These results are used as a benchmark to proceed to the next session or not. This research is said to be successful if the percentage of class activeness and completeness of classical learning outcomes reaches $75 \%$, with the minimum completeness criteria is 75 .

\section{RESULT AND DISCUSSION}

Classroom action research has been carried out in class XI MIPA 4, Public Senior High School of 3 Bengkulu City. This research was conducted in 2 cycles consisting of planning, implementing, observing, and reflecting. Initial or pre-cycle scores to see students' abilities are taken from the original value of the daily test of the reaction rate material. The analysis of of this pre-cycle score shows that the percentage of classical completeness in this class is $35.29 \%$, with an average value of 64.8 . This figure is still far below the minimum completeness criteria.

In this online learning, the platforms used are the Zoom Meeting and WhatsApp groups. Both are used optimally. The use of features on these two platforms must be maximized. The step of dividing small groups is heterogeneous, and numbering is done through the WhatsApp group. The number of groups is 8 , with each group consisting of 4-5 students. Each group member has a different number. The group and member number of this group will be made part of the account name in the zoom meeting later. Each group has provided a textbook and supporting references regarding the material to be discussed

Furthermore, all students take part in learning through zoom meetings to get questions that need to be discussed. After that, they were in a small group discussion using the breakout room feature. After sufficient discussion, students were returned to the main room to carry out the answer stage. This is what distinguishes the NHT model in online learning. In offline learning, small groups discuss every single question, whereas, in online learning, questions are given at the beginning before they discuss.

\section{Learning Cycle I}

At the beginning of this cycle, students are given an explanation of the learning steps that will be carried out today. The learning process in the first cycle carried out by the researcher is to optimize the interaction between students and between students and teachers so that the learning process does not only take place in one direction through group activities. The material used in this first cycle is an introduction to chemical equilibrium and the factors that affect the shift in equilibrium. The learning cycle I was carried out for two meetings with the details of the first meeting being held for 90 minutes, the second meeting being held for 45 minutes, and the other 45 minutes being used for the post-test. The learning process is carried out using the Zoom meeting platform. The use of a virtual face-to-face-based platform is in accordance with the needs of students in online learning [14] — the increase in the results of the cycle can be seen in Figure 1. 


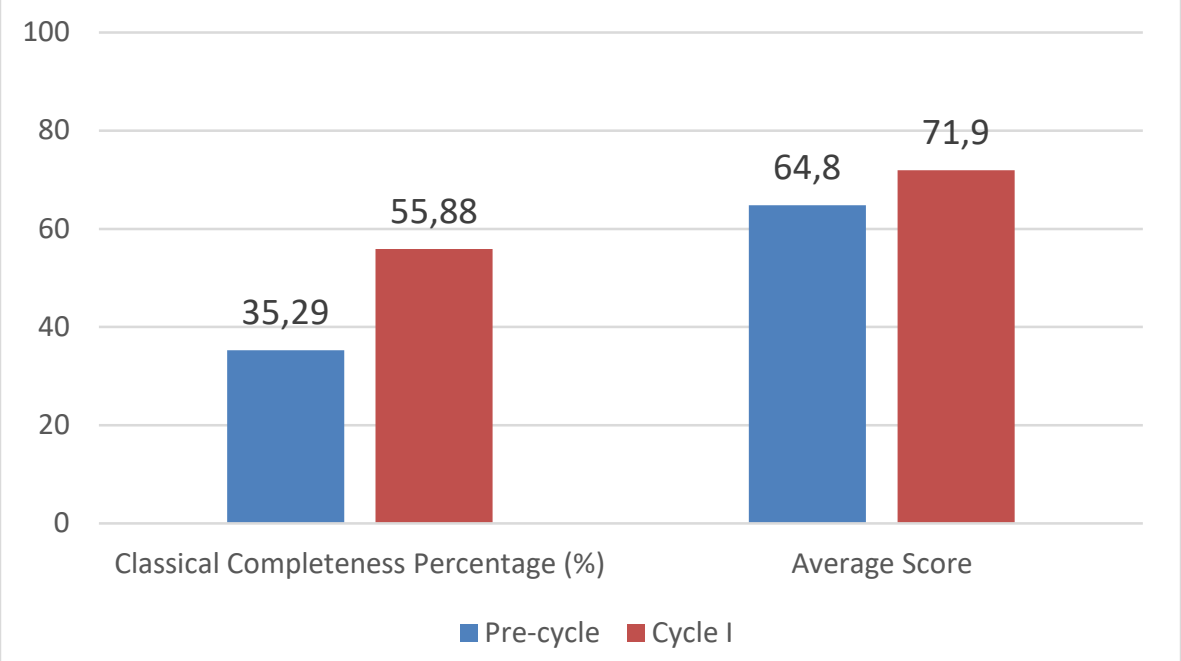

FIGURE 1. Comparison of the Classical Completeness Percentage and Average Score in Pre-Cycle and Cycle I

From this figure, it can be seen that the percentage of classical completeness and the average value has increased. The rate of classical completeness increased by $20.59 \%$, and the average score increased by 7.1. The results of observations of student activeness in learning can be seen in Table 1.

TABLE 1. The Percentage of Students Activeness

\begin{tabular}{lc}
\hline \multicolumn{1}{c}{ Aspects } & Percentage \\
\hline Issuing opinions during group discussions & $50 \%$ \\
\hline Providing appropriate arguments & $44,11 \%$ \\
\hline Providing relevant questions & $26,47 \%$ \\
\hline Percentage Average & $40,19 \%$ \\
\hline
\end{tabular}

During group discussions, each group is given a discussion worksheet that obtaining the questions that must be answered. After students work on the discussion worksheet, students are given directions to discuss the discussion worksheet that has been given based on the sources of information they have obtained. one1 observer accompanied the group discussion process. This observation is helpful for knowing the activeness of students in the group. There are groups where all members are active, but there are also groups where only a few members are involved.

After conducting group discussions, students are returned to the main room to carry out the answering stage. At this stage, the teacher mentions the group's name followed by several group members to answer questions from the teacher. If the student cannot answer, another group with the same number will be thrown. Other students from different groups are given the opportunity to respond, argue or ask questions that are still relevant to the teacher's question. This learning process takes place actively and is conducive. Students who will speak must use the raise hand feature at the zoom meeting.

From the results of class activeness observations, there were nine students who had very active criteria, seven students who had active criteria, and two students who had moderate active criteria. The rest are in the criteria of less active and inactive. There are many obstacles faced by students when carrying out learning using this NHT learning model. The main block in online learning is the provider network. The powerful network will not provide good video conferencing quality. This is in accordance with previous research that the network is one of the obstacles in online learning $[15,16]$. These constraints can cause students not to be maximal in participating in learning. Even in small group discussions, many students only rely on their group mates to give their opinion. When the student gets a turn to answer, the student only offers a modest answer. The student also did not provide arguments and responses to his friends. This makes the student's activeness scoreless. 
From the post-test results, it was found that many students experienced the incompleteness of certain sub-materials. This incompleteness is experienced in many sub-material factors that affect the shift in equilibrium in the temperature and concentration sections. Many students find it challenging to determine the direction of the equilibrium shift when the temperature is increased, the concentration is increased, or vice versa. However, for other factors, most students have determined the direction of the shift in the equilibrium of a reaction.

The percentage of classical completeness and the average rate of class activeness is still below the expected target. This becomes material for reflection to continue to the next cycle. The shortcomings in cycle I are used as material for improvement for cycle II so that it is better and reaches the expected target. Learning Cycle II

The implementation of cycle II consists of one meeting for 90 minutes, one session for 45 minutes, and 45 minutes as a post-test. The material in this second cycle is the equilibrium constant plus the factors that affect the equilibrium shift for the temperature and concentration factors. The factors influencing this equilibrium shift are repetition material from cycle I which has a relatively high level of incompleteness. The comparison of the percentage of classical completeness and the average value of cycle I and cycle II can be seen in Figure 2.

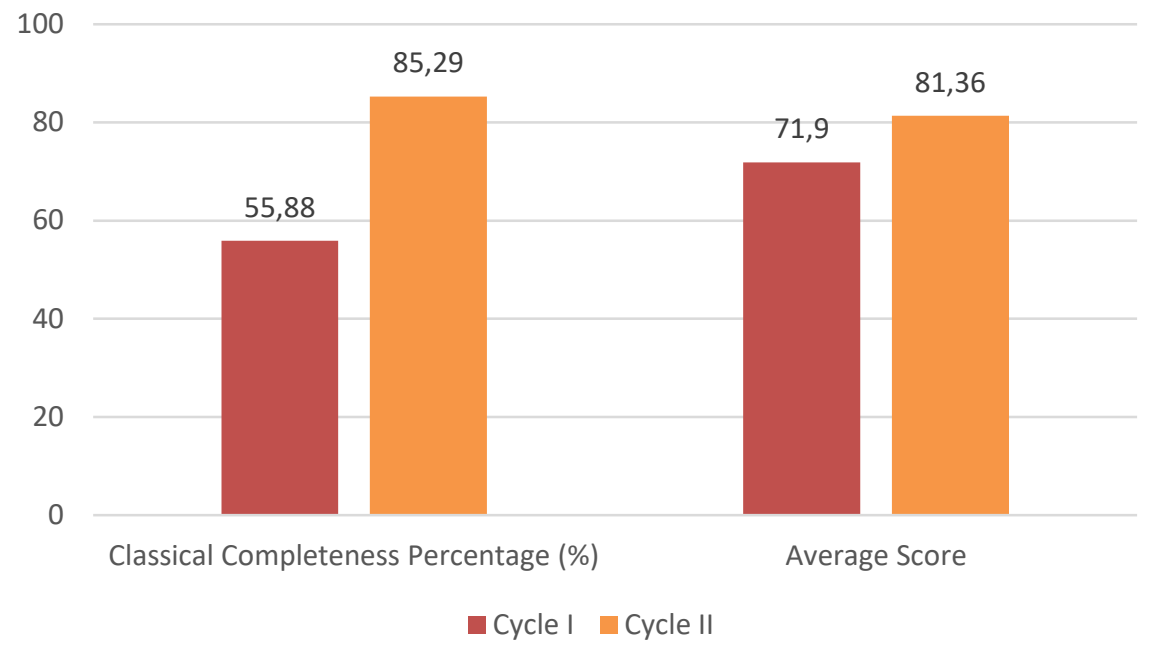

FIGURE 2. Comparison of the Classical Completeness Percentage and Average Score in Cycle I and Cycle II

In Figure 2, the increase in the percentage of classical completeness from cycle I to cycle II is $29.41 \%$, while the classical average value increases by 9.46 . The rate of student activeness aspects in cycle II online learning can be seen in Table 2.

TABLE 2. The Percentage of Students Activeness

\begin{tabular}{lc}
\hline \multicolumn{1}{c}{ Aspects } & Percentage \\
\hline Issuing opinions during group discussions & $88,24 \%$ \\
\hline Providing appropriate arguments & $82,35 \%$ \\
\hline Providing relevant questions & $76,47 \%$ \\
\hline Percentage Average & $82,35 \%$ \\
\hline
\end{tabular}

In cycle II, students were given a discussion worksheet at the beginning of the meeting and divided into small groups through the breakout room feature. The division of groups and numbers for each student is equated with cycle I. Observations in small groups are still carried out to determine students' activeness. Most of the groups had active and lively discussions than the group discussions in the previous cycle. In terms of quality, the activeness of students in the small group discussion process has increased. There were students who were not active at all before; in this cycle, they were more active in arguing. After 
sufficient small group discussions, the students were returned to the main room to carry out the next stage, namely answering. The teacher then points to the name of the group followed by the number of one member to answer. Other students are allowed to respond or rebut after the designated student has finished answering. Of course, by using the raise hand feature on the Zoom meeting platform. After being allowed by the teacher, other students can only respond or argue.

In cycle II, class discussion on a topic is more lively than in the previous cycle. Many students provide arguments and questions that are relevant to the material being discussed. The number of students who expressed their opinions was more than the previous cycle. The observation results stated that there were 12 students with very active criteria, nine students with active criteria, seven students with moderate active criteria, and the rest were in the less active and inactive criteria. This result had an increase compared to cycle I. The students had overcome many problems regarding the network by looking for a place that had a more robust network. They also want to be more active in this learning. On the other hand, also in cycle II, the teacher provides more motivation and will give appreciation to students who are more active in learning chemistry. This makes students more interested in taking chemistry lessons online.

Table 2 shows that each aspect of observation and the average percentage of student activeness in the online learning process has increased compared to the results of observations in cycle I. This increase is in accordance with the quality in the group discussions discussed earlier. This supports previous research that the NHT model can improve student learning activities [17]. As for the learning outcomes obtained from the post-test results, most of the students have completed studying the factors that affect the shift in the equilibrium in the temperature and concentration factors, as well as the equilibrium constant. There is a small proportion of students who cannot differentiate between $\mathrm{Kc}$ and $\mathrm{Kp}$. This must be implanted further in remedial so that students understand more about chemical equilibrium material. Even so, the percentage of classical completeness and the average value for cycle II was higher than cycle I and had reached the target set at the beginning of the study. This increase is in accordance with previous research regarding the effect of the NHT model on learning outcomes [18]. The use of the NHT learning model is superior to conventional models [19].

The numbered head together $(\mathrm{NHT})$ cooperative learning model is a learning model that prioritizes small group discussions in the learning process. Group discussions are a method of learning that can change student behavior to be more active in expressing opinions [20]. Students will be more courageous in explaining the ideas or ideas they think of to their group friends [21]. In addition, group discussions can train students' responsibility for the assignment given [22]. The tasks given in this study are the questions the teacher asks to become a problem that must be resolved. Learning with NHT is proven to increase student activeness and student learning outcomes on chemical equilibrium material.

\section{CONCLUSION}

Classroom Action Research (CAR) on chemical equilibrium material in class XI MIPA 4, Public Senior High School 3 Bengkulu City has been carried out well. Overall, there was an increase in student activity in the online learning process and student learning outcomes. The percentage of student activeness in online learning increased from $40.19 \%$ in cycle I to $85.29 \%$ in cycle II. Meanwhile, the percentage of student learning outcomes completeness increased from $55.88 \%$ in the first cycle to $82.35 \%$.

The use of innovative learning models can continue to be carried out to become more interested in learning in the classroom, especially when learning online. Involving students in group discussions can be a suitable method so that students are more active and can express their opinions freely.

\section{REFERENCES}

1. Estrapala, S. \& Reed, D. K. Goal-Setting Instruction: A Step-by-Step Guide for High School Students. Interv. Sch. Clin. 55, 286-293 (2020).

2. Pane, A. \& Dasopang, M. D. Belajar Dan Pembelajaran. FITRAHJurnal Kaji. IImu-ilmu Keislam. 3, 333-352 (2017).

3. Sun, D., Looi, C. \& Xie, W. Collaborative inquiry with a web-based science learning environment: when teachers enact it differently. Educ. Technol. Soc. 17, 390-403 (2014).

4. Öztürk, I. H. Curriculum reform and teacher autonomy in turkey: the case of the history teaching. Int. J. Instr. 4, 1694-609 (2011).

5. Subagtio, M. E. Perspektif mahasiswa ips terhadap pembelajaran virtual pada masa pandemi 
COVID-19. Socius; J. Pendidik. dan Pembelajaran Ilmu Pengetah. Sos. 9, 155-168 (2020).

6. Gunawan, I. Indonesian Curriculum 2013: Instructional Management, Obstacles Faced by Teachers in Implementation and the Way Forward. Adv. Soc. Sci. Educ. Humanit. Res. 128, 56-63 (2017).

7. Dalle, F. A. \& Muharram, M. Analisis Implementasi Kurikulum 2013 terhadap Pembelajaran Kimia di SMA Negeri se-Kabupaten Wajo. Chem. Educ. Rev. 4, 133-141 (2021).

8. Suzerli, T. F., Alberida, H. \& Yogica, R. Effect of Cooperative Learning Model Numbered Head Together (NHT) to Social Attitudes Toward Competency Seventh Grade Students of SMPN 1 Padang. Bioeducation J. 3, 17-26 (2019).

9. Sutipnyo, B. \& Mosik, M. The Use of Numbered Heads Together (NHT) Learning Model with Science, Environment, Technology, Society (SETS) Approach to Improve Student Learning Motivation of Senior High School. J. Pendidik. Fis. Indones. 14, 26-31 (2018).

10. Mahmud, S. \& Idham, M. Strategi Belajar Mengajar. (Syiah Kuala University Press, 2017).

11. Solikhin, F., Ikhsan, J. \& Sugiyarto, K. H. A need analysis in developing virtual laboratory according to the chemistry teachers. J. Phys. Conf. Ser. (2019) doi:10.1088/1742-6596/1156/1/012020.

12. Maisyarah. Meningkatkan hasil belajar dan aktivitas siswa melalui model pembelajaran kooperatif tipe nht. Math Didact. J. Pendidik. Mat. 1, 125-131 (2015).

13. Anugrah, M. Penelitian Tindakan Kelas (Langkah-Langkah Praktis Pelaksanaan Penelitian Tindakan Kelas. (Leutikaprio, 2019).

14. Handayani, D. The Application of The PjBL Model uses WhatsApp and Zoom Meetings in Learning. Int. J. Chem. Educ. Res. 4, 46-52 (2020).

15. Saragih, O., Sebayang, A. A., Sinaga, A. B. \& Ridlo, M. R. Persepsi mahasiswa terhadap pembelajaran daring selama pandemi COVID-19. Tarb. Wa Ta'lim J. Penelit. Pendidik. Pembelajaran 7, 124-132 (2020).

16. Akmal, A., Fikri, A., Rahmawati, T., Hendri, Z. \& Sari, N. Measuring online learning readiness during corona virus pandemic: an evaluative survey on history teachers and students. J. PAJAR (Pendidikan dan Pengajaran) 5, 98-110 (2021).

17. Nurpaidah, S. Penerapan Model Pembelajaran Kooperatif Tipe Numbered Heads Together (NHT) terhadap Aktivitas Belajar Siswa pada Materi Ikatan Kimia Kelas X 1 SMA Negeri 3 Watampone. Chem. J. Ilm. Kim. dan Pendidik. Kim. 19, 20-16 (2018).

18. Mauliza. Improving 'Students' Learning Result Using Numbered Heads Together Model. Int. J. Educ. Vocat. Stud. 2, 301-303 (2020).

19. Febiliyanti, R., Tiwow, V. \& Gonggo, S. Pengaruh Model Pembelajaran Kooperatif Tipe NHT (Numbered Heads Together) Terhadap Hasil Belajar Siswa Kelas XI IPA SMA Negeri 1 Dolo Pada Materi Pelajaran Kimia Koloid. J. Akad. Kim. 3, 98-103 (2014).

20. Malik, J. Penerapan Metode Diskusi Kelompok Untuk Meningkatkan Hasil Belajar Ipa Dan Aktivitas Siswa Kelas IV Sd I Sidorekso Pada Materi Menggolongkan Hewan Berdasarkan Jenis Makanannya. Refleks. Edukatika J. IIm. Kependidikan 9, 128-133 (2019).

21. Putriyanti, C. C. \& Fensi, F. Penerapan Metode Diskusi Kelompok untuk Meningkatkan Hasil Belajar Siswa pada Mata Pelajaran IPS di Kelas IX SMP Santa Maria Monica, Bekasi Timur. Psibernetika 10, 114-122 (2017).

22. Kelirik, N. Penerapan Metode Diskusi Kelompok untuk Meningkatkan Hasil Belajar IPA di Sekolah Dasar Negeri 1 Sukadana. J. Chem. Inf. Model. 53, 1-11 (2013). 